\title{
SOME ASPECTS OF SOCIALIST MODERNIZATION IN THE CROATIAN CITIES
}

\author{
Mario BARA*
}

The paper focuses on the period of socialist modernization in Croatian urban settings, in a country guided by ideologically shaped administrative measures, absence of social pluralism, and private economic initiatives. The socialist regime mainly promoted the announced transformation of social and economic relations, as well as technical progress, in the urban areas, where cultural and symbolic interventions took place along with the technical ones. The socialist city was to become an ideal city that met all the needs of the "working people". Industrialization and urbanization caused labour migration from rural to urban areas. Due to the large number of new residents in the cities, the authorities paid much attention to housing policies. Accelerated construction resulted in a discrepancy with the existing urban and communal infrastructure. The consequences of half a century of socialist modernization in the cities were most evident in the altered population structure. At the beginning of the observed period, only one quarter of the population lived in cities, but when the socialist epoch ended, this ratio was over $50 \%$. The negative consequences of socialist modernization in the cities could be seen in the polarized development of the main urban centres, the unevenly developed network of medium-sized and small towns, and the depopulation of a significant part of rural areas.

Keywords: socialist modernization, cities, urbanization, Croatia

1 This research has been financed by the Croatian Science Foundation, project IP-2016-06-2015: Modernization of Urban Life in Croatia through the Prism of Communal Infrastructure Development in the $19^{\text {th }}$ and $20^{\text {th }}$ Centuries.

Mario Bara, Ph. D., Catholic University of Croatia, Zagreb, Croatia 


\section{Introduction}

Transformation of traditional societies into modern ones implies a complex set of processes that can simultaneously increase the number of institutions and substitute simple social structures through complex ones. Owing to the historical and cultural circumstances, Croatia was among the societies that started these modernization processes with a delay and displayed discontinuities in technical, industrial, and political-cultural modernization. The main causes included the administrative-political and territorial division of Croatia, its lack of political independence as part of multinational states in the $19^{\text {th }}$ and 20 th centuries, uneven economic development, wars, and changes in the political system, as well as the changing modernization patterns and geographical diversity between the Pannonian, Mediterranean, and Dinaric regions.

According to Émile Durkheim, the division of labour is one of the key elements that separate traditional from modern societies. Thus, the division of labour creates a more complex society, a new type of integration, and social solidarity that he called organic and associated with the industrial societies. ${ }^{2}$ According to Max Weber, an equally important factor is the rationalization process and control over the physical and social environment, as an essential feature of modern societies. ${ }^{3}$ Rationalization is manifested in the development of a capitalist society and a bureaucratically organized state as the most efficient and most rational social mechanism for mobilizing and implementing collective social action. ${ }^{4}$ Relying on Durkheim and Weber, Talcott Parsons saw the emergence of modernity through the prism of differentiation between the central functional systems: "economy (adjustment), politics (achieving goals), social community (integration), and culture (maintaining value patterns)."5 He observed various societies in their transformation from simple to more complex, along with the processes of social change. These processes could be triggered in many different ways, mostly by changes in technology and/or values, and the main conclusion of this theory was that the developing countries should accept the modern Western model in terms of social system and culture if they wanted to develop. Parsons's theory of modernization was very influential in the 1960s and 1970s. However, it was criticized as reflecting an

\footnotetext{
2 Émile Durkheim, The Division of Labor in Society (New York: The Free Press, 1947), pp. 336337.

3 Edward Royce, Classical Social Theory and Modern Society: Marx, Durkheim, Weber (Lanham, Boulder, New York, and London: Rowman \& Littlefield, 2015), pp. 96-97.

4 Ibid., p. 152.

Wolfgang Merkel, Eine Einführung in die Theorie und Empirie der Transformationsforschung (Opladen: Leske + Budrich bei UTB, 1999), p. 79.
} 
ethnocentric (Western) worldview. ${ }^{6}$ During the Cold War, it was believed that "development" and "modernization" were long-term solutions to the threat of political instability and the influence of Communism in the Third World.? Seymour M. Lipset suggested that Communism would weaken with the rise of modernization and democracy would be strengthened. Namely, democracy was positively related to the national achievements in economic development, including the national level of educational achievement. ${ }^{8}$ On the other hand, Communist regimes used the programme of social modernization as a justification for seizing power. ${ }^{9}$ In the early years of rule (1945-1948), the Yugoslav Communists sought to consolidate their social values, regime of government, the single-party system, planned economy, and their control over public opinion according to a model developed in the USSR. In order to achieve rapid technical modernization, and considering the lack of industry, machines, skilled workers, and raw materials, they applied the model of socialist competition and glorifying labour. ${ }^{10}$ After 1948, Yugoslavia liberated itself from the Soviet control and was among the first states to abandon blind implementation of the Soviet economic and institutional model of modernization, conducting various economic experiments with the liberalization and decentralization of economy. ${ }^{11}$

\section{Croatian modernizations}

When it comes to modernization in Croatia, one must approach it as a plural, heterogeneous phenomenon characterized by numerous discontinuities. Perhaps it is better described by saying that Croatia was marked by "several modernization attempts (models), clearly separated by structural cuts." ${ }^{12}$ In this region, modernization models were considerably different from those in the Western European countries. One may speak of delayed industrialization, slower transition from a traditional pre-industrial to an industrial society,

6 Dean C. Tipps, "Modernization Theory and the Comparative Study of Societies: A Critical Perspective," Comparative Studies in Society and History 15 (1973), no. 2: 206.

7 Ibid., p. 210.

8 Seymour M. Lipset, Political Man: The Social Bases of Politics (New York: Doubleday, 1960), p. 129.

9 Merkel, Eine Einführung in die Theorie und Empirie der Transformationsforschung, p. 37.

10 Tomislav Anić, "Socialist Competition from Soviet Union to Yugoslavia", Review of Croatian History 13 (2017), no. 1: 183-184.

11 Dennison Rusinow, "Understanding the Yugoslav Reforms", The World Today 23 (1967), no. 2: 71

12 Ivan Rogić, "Tri hrvatske modernizacije i uloga elita" ["Three Croatian modernizations and the role of elites"], in: Upravljačke elite i modernizacija, ed. Drago Čengić and Ivan Rogić (Zagreb: Institut društvenih znanosti Ivo Pilar, 2001), p. 39. 
slower development of cities, and a specific type of industrialization dominated by the processing industries catering for the needs of other centres of economic and political power, located outside Croatia. ${ }^{13}$

As for the time frame of these Croatian modernizations, we will use the results of sociologist Ivan Rogić, who has sought, along with establishing a chronology, to explain these processes by using sociological methods. ${ }^{14} \mathrm{He}$ has identified three processes as defining modernization in Croatia: industrialization, urbanization, and bureaucratization. Focusing particularly on technical modernization, he has indicated it as a key element in carrying out the modernization program, i.e. total modernization of the society. ${ }^{15}$ Rogić has divided modernization in Croatia into three periods: a) the first modernization period from 1868 to 1945 ; b) the second modernization period at the time of socialism, from 1945 to 1990; and c) the third modernization period that started in 1991. Analysing the first modernization period in Croatia, the author has viewed it in the context of double periphery and the lack of political autonomy. Political and economic power was concentrated in the centres of multinational states to which Croatia belonged, while its periphery was marginalized and fundamentally defined by a lack of infrastructure.

These circumstances, particularly dependence on different political centres and an insufficient development potential owing to the predominantly agrarian structure of the population before the mid-20th century, influenced the pace of Croatia's progress over the long term. Thus, the first modernization period was characterized by private initiative and private capital, as well as an uneven development of the northern regions with regard to Dalmatia and Istria, due to the administrative and political division of the Croatian lands between Austria and Hungary ${ }^{16}$ Rudimentary forms of industry prevailed in the domain of processing agrarian and forestry industries. ${ }^{17}$ In such a socio-economic, transportation, and political situation of fragmented territories and non-unified economy, Croatian cities and towns, despite the demographic

\footnotetext{
13 Maja Štambuk, "Selo i modernizacija: kratka povijest nesporazuma" ["The village and modernization: A brief history of misunderstanding"], in: Prostor iza: kako modernizacija mijenja hrvatsko selo, ed. Maja Štambuk, Ivan Rogić, and Anka Mišetić (Zagreb: Institut društvenih znanosti Ivo Pilar, 2002), pp. 14-15.

14 Ivan Rogić, Tehnika i samostalnost: Okvir za sliku treće hrvatske modernizacije [Technology and autonomy: A frame for the picture of the third Croatian modernization] (Zagreb: Hrvatska sveučilišna naklada, 2000).

15 Ibid., p. 613.

16 Igor Karaman, Privreda i društvo Hrvatske u 19. stoljeću [Croatian economy and society in the $19^{\text {th }}$ century] (Zagreb: Školska knjiga, 1972).

17 Igor Karaman, "Uloga malog i srednjeg poduzetništva u oblikovanju kapitalističkog privrednog sustava na tlu Hrvatske" ["The role of small and middle entrepreneurs in the formation of capitalist economic system in Croatia"], Povijesni prilozi 9/9 (1990): 12.
} 
progress, were still insufficiently industrialized and infrastructurally developed to become a stronger generator of development in the Croatian society of the time. ${ }^{18}$

\section{Socialist modernization}

In this paper, I will primarily focus on the second or socialist modernization period in Croatia, with its impact on urban entities. After World War II, half a century of modernization began in Croatia that was carried out by political means and aimed at breaking up with the traditional structures. It was characterized by a lack of plurality in the society and of private economic initiative. Ralf Dahrendorf has called this type of modernization "modernization without modernity." ${ }^{19}$ Ivan Rogić has also referred to it as "paradoxical modernization" because it was realized within the proclaimed "self-management model" of social organization, aimed at demonstrating the existence of democracy in a totalitarian setting. ${ }^{20}$ When it comes to the character of the Yugoslav state in the period from 1945 to 1990, political scientists do not agree on its classification. It was a "special case" with elements of a totalitarian state, but without all the assumed characteristics listed in the typology of Friedrich and Brzezinski ${ }^{21}$ that would classify it as such. ${ }^{22}$

Post-war socialist modernization implied that the state had acquired far-reaching powers. The government announced a rapid economic and social transformation and improvement in the quality of life. ${ }^{23}$ Croatia emerged from the war with a dismantled industry, which had been underdeveloped even before the war, as well as a weakened economy, insufficient basic infrastructure, and a large number of demolished and damaged housing facilities. The socialist regime mainly promoted the announced transformation of social and economic relations, as well as technical progress, in the urban areas, where cultural and symbolic interventions took place along with the technical ones.

\footnotetext{
18 Jakov Gelo, Demografske promjene u Hrvatskoj od 1780. do 1981. [Demographic changes in Croatia, 1780-1981] (Zagreb: Globus, 1987), p. 100.

19 Ralf Dahrendorf, “The Strange Death of Socialism," Studies: An Irish Quarterly Review 79 (1990), no. 313: 12.

20 Rogić, Tehnika i samostalnost, p. 496.

21 Carl J. Friedrich and Zbigniew K. Brzezinski, Totalitarian Dictatorship and Autocracy (New York: Praeger, 1956).

22 Sergej Flere, "Da li je Titova država bila totalitarna?" ["Was Tito's state totalitarian?"], Političke perspektive 2 (2012), no. 2: 17-18; Rusinow, “Understanding the Yugoslav Reforms", p. 71.

23 Vlado Puljiz, "Socijalna politika i socijalne djelatnosti u Hrvatskoj u razdoblju 1900.-1960. godine" ["Social policy and social work in Croatia, 1900-1960"], Ljetopis Studijskog centra socijalnog rada 13 (2006), no.1: 20-21.
} 
The socialist city was to become an ideal city that satisfied all the needs of the working people from which the "class of urban workers as the carriers of development in the new, socialist society" would develop. ${ }^{24}$

It was to be a new type of city, a prototype for realizing the "socialist way of life" in which, along with the right of workers to the city, work, and housing, considerable attention was paid to culture and recreation..$^{25}$ An example of such a city in Croatia was the newly constructed district of Novi Zagreb (New Zagreb).

\section{Housing architecture}

The post-war period was characterized by a chronic lack of housing. Two key factors may help explain this situation: firstly, many cities had reduced housing facilities due to war destruction, such as Zadar and Split, and secondly, the state initiated intensive industrialization that triggered the influx of new population. Industrialization was partly based on the already existing industry from the earlier period. With the 1946 Constitution of the FNRJ, the state undertook to improve the housing conditions (Article 20). In order to alleviate the shortage of housing, a short-term model of condominiums was implemented, and the housing stock was also filled with nationalized and confiscated apartments. A provision was issued on the maximum of rooms that one family could have, and the excess space was taken away and given for use to those who did not own an apartment. ${ }^{26}$ Housing cooperatives were established with the aim of securing land for the construction of residential buildings and public construction works (roads, sewage, water supply, pavements, urban landscaping, etc.). ${ }^{27}$ The improvement of housing was stated in the Law on the Five-Year Plan of NR Croatia from 1947 to 1951, which foresaw the construc-

\footnotetext{
24 Goran Korov, "Zajednička ili zasebna? Paradigme u arhitekturi socijalističke Jugoslavije” ["Joint or separate? Paradigms in the architecture of socialist Yugoslavia”], Kvartal: kronika povijesti umjetnosti u Hrvatskoj 9 (2012), no. 3-4: 52.

25 Rosemary Wakeman, "Was There an Ideal Socialist City? Socialist New Towns as Modern Dreamscapes," in: Transnationalism and the German City. Studies in European Culture and History, ed. Jeffry Diefendorf and Janet Ward (New York: Palgrave Macmillan, 2014), p. 106.

26 Sanja Klempić, "Razvoj stambenih naselja Splita nakon Drugog svjetskog rata" ["Development of housing estates in Split after World War II"], Hrvatski geografski glasnik 66 (2004), no. 2: 96; Đorđe Alfirević and Sanja Simonović-Alfirević, "Urban housing experiments in Yugoslavia 1948-1970," Spatium 34 (2015): 4-5.

27 Arhiv Jugoslavije [Archives of Yugoslavia, AJ], fund no. (f) 41, Savezna planska komisija [Federal Planning Commission, SPK], Nacrt pravila Stambene zadruge Zagreb [Draft rulebook for the Housing Association Zagreb], box 536.
} 
tion of 15 million $\mathrm{m}^{2}$ of new residential areas and 1 million $\mathrm{m}^{2}$ for schools. ${ }^{28}$ However, despite the invested efforts and resources, housing construction failed to keep pace with the dynamics of rural-urban migration. The beginning of the construction of planned settlements for workers can be linked to the adoption of the five-year plan. It was considered that collective housing was the best model as a socially organized way of solving the housing problems. However, in the cities of the 1960s, there was a growing volume of individual or private construction as well. In 1964, individual construction still amounted to $57.6 \%$ of the total housing construction, in 1965 it was $62.4 \%$, and in 1967 it rose to $64.7 \%$ of the total housing construction. ${ }^{29}$ For a segment of the population, individual construction was the only way to solve their housing problem. Moreover, the existing model of collective housing could not offer luxury apartments in terms of surface area and gardens, something that only private houses could provide. ${ }^{30}$ Many citizens believed that individual construction was the cheapest option, especially because it was encouraged by various measures (loans to working organizations, land allocation, etc.) and was not sufficiently replaced by more rational forms (pre-arranged land plots, rows of buildings, rational land partition). ${ }^{31}$ In the later years of this period, efforts were made to discourage individual construction by offering low rents to those who lived in state-owned apartments. ${ }^{32}$ Housing policies in the socialist self-management society underwent numerous changes: from central state distribution through various intermediaries to self-management forms. The market also played an important role, but was never allowed to develop with complete freedom. ${ }^{33}$ The initial paternalistic role of the state was gradually replaced by the greater responsibility of enterprises for providing housing to their workers. ${ }^{34}$

28 Sandra Križić Roban, “Obilježja modernosti na području arhitekture, urbanizma i unutrašnjeg uređenja nakon drugoga svjetskog rata" ["Features of modernity in architecture, urban planning, and interior design after World War II"], in: Socijalizam i modernost: umjetnost, kultura, politika: 1950.-1974., ed. Ljiljana Kolešnik (Zagreb: MSU and IPU, 2012), p. 58.

29 AJ, Savezno izvršno veće [Federal Executive Council, SIV], f 130, Savezna skupština. Komisija za urbanizam i uređenje prostora. Osnove politike urbanizacije i prostornog uređenja - teze. Januar 1969. [Federal Assembly, Commission for Urban Planning and Landscaping, Basics of Urban and Landscaping Policy - theses, January 1969], p. 6, box 749.

30 Dušica Seferagić, "Stanovanje kao pokazatelj socijalne segregacije u zagrebačkom prostoru" ["Housing as an indicator of social segregation in the Zagreb area"], Sociologija sela 47-48 (1975): 79.

31 AJ, f 41, SPK. O mogućnosti stanbene izgradnje u 1950. godini na individualnoj osnovi [On the Possibility of Individual Housing Construction in 1950], box 536.

32 Dušica Seferagić, Kvaliteta života $i$ nova stambena naselja [Quality of life and the new housing districts] (Zagreb: Hrvatsko sociološko društvo, 1988), p. 77.

33 Seferagić, Kvaliteta života i nova stambena naselja, p. 49.

34 Gojko Bežovan, "Stanovanje i stambena politika" ["Housing and the housing policy"], in: Socijalna politika Hrvatske, ed. Vlado Puljiz (Zagreb: Pravni fakultet Sveučilišta u Zagrebu, 2008), p. 339. 
Accelerated and continuous increase in the number of inhabitants resulted in an aggravated housing crisis and the emergence of uncontrolled construction. A considerable part of private houses in the 1960s were built illegally ( $47 \%$ in a sample of 70 surveyed cities). ${ }^{35}$ There are numerous reasons why people resorted to illegal construction, such as the inability to solve their housing problems by themselves or to bear all the costs of legal construction, but also the absence of urban planning and land policy, the inadequacy of local regulations, and the disorganization of communal and inspection services. ${ }^{36}$ These were new settlements on the outskirts of cities, in which the owners of illegally constructed buildings owned the land on which they built. This is a significant difference in relation to the developing countries, where illegal construction largely emerged on usurped land. ${ }^{37}$ The fundamental feature of illegally built houses was that they were usually grouped on the city margins, where building land was cheaper, and that their residents shared similar lifestyles, mentalities, and everyday problems. ${ }^{38}$ Split faced the problem of illegal construction as early as the $1950 \mathrm{~s},{ }^{39}$ but so did Zadar, ${ }^{40}$ Zagreb ${ }^{41}$ and to a lesser extent some other cities. Many of the migrants could not cope with the new environment, because the urban way of life required them to change their old habits. Thus, in some of the new urban settlements, the rural lifestyle continued to be practiced for quite a while. For example, in the 1970s, Zagreb grew by an average of 15,000 inhabitants or around 5,000 families each year. For comparative purposes, one should note that many settlements in Croatia had less than 15,000 inhabitants in total, although the state statistics classified them as cities. Two thirds of their new residents were immigrants. ${ }^{42}$ From the 1960s, Južni Zagreb (South Zagreb) was a new immigration area (from 1975 called New Zagreb) and was to become home to 250,000 inhabitants, according to the plans. It was only after World War II that Zagreb began to

\footnotetext{
35 AJ, f 130, SIV, Savezna skupština. Komisija za urbanizam i uređenje prostora. Osnove politike urbanizacije i prostornog uređenja - teze. Januar 1969. [Federal Assembly, Commission for Urban Planning and Landscaping, Basics of Urban Planning and Landscaping Policy - theses, January 1969], p. 6, box 749 .

36 Ibid.

37 Klempić, "Razvoj stambenih naselja Splita nakon Drugog svjetskog rata”, 96.

38 Ibid., 112.

39 Hrvatska [Croatia, HR], Državni arhiv u Splitu [State Archives in Split, DAST], Urbanistički zavod Dalmacije [Dalmatian Institute for Urban Planning Split (UZDS)], f 119, Slobodan Bjelajac, Bespravna stambena izgradnja u Splitu [Illegal housing construction in Split], 1970.

40 Jasna Galjer and Anđela Galić, "Kultura stanovanja u Zadru 1950-ih u kontekstu afirmacije modernizma" ["Housing culture in Zadar during the 1950s and the affirmation of modernism"], Ars Adriatica 7 (2017): 320-321.

41 Seferagić, "Stanovanje kao pokazatelj socijalne segregacije u zagrebačkom prostoru”, 70.

42 Ibidem, 81.
} 
spread significantly towards the south, across the Sava River. ${ }^{43}$ The official policy encouraged massive and cheap construction for collective housing. In order to reduce the building costs, smaller, more modest, typified flats were built in order to alleviate the shortage of housing. Thus, new housing settlements emerged, with a minimum of surface and modest equipment, as a manifestation of the desire to solve the housing issue for as many residents as possible. ${ }^{44}$ Apartments built in such programmes were generally situated in large buildings, which thus became an important feature of socialist urbanization. ${ }^{45}$

Segregation was noticeable in all major socialist cities. ${ }^{46}$ Mechanisms that led to segregation in housing were numerous, the most important ones being the uneven allocation of apartments to specific social groups (according to their education, position in the political hierarchy, or employment), the date of construction, and unequal access to land for private construction. ${ }^{47}$ Research conducted in the mid-1970s confirmed that, despite the proclaimed values, there was social segregation in housing. There were settlements of workers, who lived in modest houses with insufficient infrastructure and generally in poorer living conditions, as well as zones with officials and craftsmen, who lived in better-quality houses and well equipped urban settlements. ${ }^{48}$ In the 1980s, urban immigration gradually slowed down due to an acute economic crisis in the country, which helped stabilize the housing situation. It was in the same period that the housing market developed, based partly on the law of supply and demand. Acquisition of apartments largely depended on the financial power of individual companies whose employees contributed to the housing construction with a percentage of their salaries. A part of these financial resources was put together for "solidarity apartments" at the local government level. However, the distribution of these funds resulted in new social disparities, since some of the workers contributed for decades and never obtained tenant rights. The socialist period was characterized by the concept of "social apartments", which was one of the symbols of socialist organization, as it reflected the idea of social ownership and promoted social justice. ${ }^{49}$ In the total housing stock, $25 \%$ of all apartments were social apartments, mainly

43 More details on the construction of New Zagreb in: Valentina Gulin Zrnić, Kvartovska spika: Značenje grada i urbani lokalizmi u Novom Zagrebu [Talk of the neighbourhood: Meanings of the city and urban localisms in New Zagreb] (Zagreb: Jesenski i Turk, 2009).

44 Seferagić, Kvaliteta života i nova stambena naselja, p. 82.

45 Bežovan, Stanovanje i stambena politika, p. 339.

46 Smith, "The Socialist City," 96-98.

47 Ibid.

48 Seferagić, “Stanovanje kao pokazatelj socijalne segregacije u zagrebačkom prostoru," 81.

49 Tin Sven Franić, Luka Korlaet, and Dubravka Vranić, "Prilog analizi stambenih politika i planske stanogradnje Nizozemske i Hrvatske" ["Contribution to an analysis of housing policies and planned housing construction in the Netherlands and in Croatia"], Prostor 13 (2005), no. 2: 199. 
concentrated in larger cities. In Zagreb, as the largest city in Croatia, social apartments accounted for $45 \%$ of the housing stock in the later socialist period. ${ }^{50}$

\section{Communal construction}

Socialist modernization took place along with accelerated industrialization and urbanization, which triggered migrations and demographic growth, resulting in an urgent need for housing and a discrepancy with the existing urban and communal infrastructure. This was reflected in the growing need of roads, electrification, gasification, water supply and sewage systems, new schools, kindergartens, cultural facilities, urban landscaping, and other elements of infrastructure. The authorities in charge sought for new options to build better, faster, and cheaper. ${ }^{51}$ Nevertheless, a large number of buildings remained unfinished for years. Thus, the planned settlements further away from the city centres were often without the basic facilities for children, service shops, and the accompanying communal infrastructure. ${ }^{52}$

It was obviously necessary to allocate additional finances for the construction of schools and other facilities in the new settlements. ${ }^{53}$ One of the conclusions at the meeting of the Permanent Assembly of Yugoslav Cities that took place in Maribor in 1953 was that the said discrepancy was "the gravest problem of these cities." ${ }^{4}$ It was calculated that the optimum surface area per student (the total classroom area divided by the total number of schoolchildren) was $2 \mathrm{~m} 2$, but in 1956 it amounted to $0.94 \mathrm{~m} 2$ in Croatia. In larger cities, this situation was even worse. In Osijek, it was $0.63 \mathrm{~m} 2$, in Karlovac 0.54 m2, in Split $0.54 \mathrm{~m} 2$, in Zagreb $0.59 \mathrm{~m} 2$, and so on. Because of this, schools often held classes in two or three, sometimes (although rarely) even more shifts. Besides that, some school buildings were used for other purposes as well, such as cultural events, housing, administrative, social, healthcare-related, commercial,

\footnotetext{
50 Bežovan, "Stanovanje i stambena politika," 339.

51 AJ-60, Komitet za lokalnu privredu i komunalne poslove [Committee for Local Economy and Communal Affairs], box 4 .

52 AJ-142, Socijalistički savez radnog naroda Jugoslavije [Socialist Union of the Working People of Yugoslavia (SSRNJ)], Stanbena zajednica kao urbanistički element planskog razvoja gradova i drugih naseljenih mesta [Housing community as an element of urban planning in the development of cities and other settlements], p. 7, box 88.

53 AJ-130, SIV, Stalna konferencija gradova Jugoslavije [Permanent Conference of Yugoslav Cities (SKGJ)], box 749 .

54 AJ-130, SIV, SKGJ, Komunalno-stambena problematika, Druga skupština Stalne konferencije gradova i gradskih općina FNRJ [Communal and Housing Issues, 2nd convention of the Permanent Conference of Yugoslav Cities and Municipalities], box 749 .
} 
and other activities. In 1956, out of a total of 399 school buildings in Croatian urban areas (according to the administrative criteria of the time), 215 were used exclusively for schooling purposes. In addition, hygiene conditions were problematic, as only $60.2 \%$ of the school buildings were connected to urban water supply. ${ }^{55}$ In the early phase of building the communal infrastructure in the 1950s, the backwardness of urban planning was among the main causes of wild development of towns and cities.

With time, more finances were invested in building communal services in collective housing settlements, by which the authorities somehow managed to satisfy the need for basic infrastructure. The situation was less promising in settlements where private construction prevailed, which was often illegal. In such settlements, communal services were minimal, which aggravated the poor quality of life of their population: the layout was irregular, with narrow streets and often without sidewalks, and the sewage system was deficient, which shows that they were built without any plan. ${ }^{56}$ Settlements with private houses occupied larger areas, the construction of communal infrastructure was more expensive, and a significantly smaller number of inhabitants lived there than in the collective housing settlements. This type of building practice was regarded as an irrational waste of space. ${ }^{57}$

The spatial growth of cities and the increase in their number of inhabitants created a need for better mobility within the cities and between the cities and their suburbs. ${ }^{58}$ This concerned particularly commuting between one's home and workplace, but also in leisure time. The construction of transportation infrastructure can be traced on the basis of the total length of city roads, asphalted surfaces, railroad construction, tram lines, shipping lines in coastal cities, construction of airports, and so on. ${ }^{59}$ With the growth of living standard, individual traffic and pressure on the existing roads increased, and so did the need for parking lots.

In addition to communal infrastructure, urban life required cohesion and integration between the city and the society. According to the sociological studies conducted in the 1970s for the needs of urban planning institutions, the citizens of new settlements expected that, after meeting the needs for ba-

\footnotetext{
55 Ibid.

56 Klempić, "Razvoj stambenih naselja Splita nakon Drugog svjetskog rata," 111.

57 Ibid., 110.

58 HR - Državni arhiv u Rijeci [State Archives in Rijeka, DARI] - 78, Savjet za saobraćaj i pomorsku privredu Narodni odbor kotara Rijeka [Council for Transportation and Maritime Economy, National Board of the Rijeka district], box 9.

59 Damir Magaš, "Urbano geografska preobrazba Zadra - Elementi prometnog sustava 1945. 1991." [“Urban and geographic transformation of Zadar: Elements of transportation system, 19451991"], Geoadria 1 (1996), no. 1: 36.
} 
sic communal infrastructure, the city should be enriched with cultural and recreational amenities. ${ }^{60}$ After the housing crisis and the occurrence of uncontrolled construction, the adoption of general master plans brought order to urban space. A special aspect was the adaptation and integration of the rural population into the urban environment, with the adoption of new living practices.

\section{Demographic consequences of the socialist modernization of cities}

Among the most common methods in measuring the degree of urbanization in a country or a region is to analyse the share of urban within the total population. However, this method is not always the most objective one. For example, poorer and underdeveloped countries may have a high concentration of population in the cities due to migration from rural areas. ${ }^{61}$

Table 1. Share of urban in the total population of Croatia, 1948-1991

\begin{tabular}{|l|l|l|l|l|l|l|}
\hline Census year & 1948 & 1953 & 1961 & 1971 & 1981 & 1991 \\
\hline $\begin{array}{l}\text { Share of urban in the } \\
\text { total population }\end{array}$ & $24.9 \% *$ & $27.1 \% *$ & $30.8 \% * *$ & $41.0 \% * *$ & $47.8^{* *}$ & $51.3 \% * *$ \\
\hline
\end{tabular}

Source: *Mladen Friganović, "O demogeografskom procesu u (ne)urbanom prostoru SR Hrvatske" ["On the demo-geographic process in the (non-)urban areas of SR Croatia"], Dela 6 (1989): 100; **Model diferencijacije urbanih, ruralnih i prijelaznih naselja $u$ Republici Hrvatskoj [Model for differentiating between urban, rural, and transitional settlements in the Republic of Croatia], Državni zavod za statistiku [State Institute of Statistics], 2011: Metodološke upute [Methodological instructions] 67, p. 19.

Before the mid-20 $0^{\text {th }}$ century, Croatia was predominantly an agrarian country with poorly developed urban centres. Stronger economic development, based partly on pre-war industry, was encouraged by the state, which prompted stronger urbanization along with industrialization. Immediately after the war, only $25 \%$ of the Croatian population lived in cities (Table 1). Cities had become the bearers of polarized development and their population increased continuously, primarily by immigration. Some of the Croatian cities had to

60 HR-DAST-119, UZDS, Program za provedbeni urbanistički plan splitskog poluotoka. Sociološka studija [Programme for the Executive Master Plan of the Split peninsula: A sociological study] (Split, 1974), p. 80.

61 Milan Vresk, "Urbanizacija Hrvatske 1981-1991.: Osnovni indikatori stupnja, dinamike i karakteristika urbanizacije" ["Urbanization of Croatia, 1981-1991: Main indicators of the extent, dynamics, and features of urbanization”], Geografski glasnik 54 (1992), no. 1: 100. 
make up for the depopulation caused by the emigration of Italians (e.g. Zadar, Rijeka, Pula, and various other Istrian cities) and Germans (Slavonia), as well as members of various other national minorities and opponents of the new regime. ${ }^{62}$ Some smaller Istrian towns have never completely recovered in terms of demography due to this post-war emigration. The resulting situation could only be changed by immigration. This is well illustrated by the example of Zadar, where, according to the census of 1961, only $25 \%$ of the population had been born there. ${ }^{63}$

The most intensive urban immigration took place between 1961 and 1971. ${ }^{64}$ Another process that strongly affected the demographic trends in the coastal area was the process of littoralization, in which population from the hinterland and the islands moved to the largest coastal cities, such as Rijeka, Zadar, and Split. This migration direction and dynamics were caused by the differences between the development levels and lifestyles between cities and villages. In the long term, modernization policies in the cities had multiple negative economic and demographic effects on the rural areas. Small and medium-sized cities were bypassed in migration, while Zagreb, Split, Rijeka, Zadar, and slightly less Osijek had fast population growth. A good indicator of this demographic polarization in Croatia at the end of the observed period are the four macro-regional centres (Zagreb, Split, Rijeka, and Osijek), as in 1991 more than $25 \%$ of the total population of Croatia lived there, with as much as $18.2 \%$ in Zagreb alone. ${ }^{65}$

\section{Conclusion}

In the observed five decades, planned modernization of the cities was conducted by means of ideologically shaped administrative measures that resulted in an industrial transformation of the state. The consequence of such modern-

\footnotetext{
62 Marica Karakaš Obradov, "Emigracije talijanskog stanovništva s hrvatskog područja tijekom Drugog svjetskog rata i poraća" ["Emigrations of Italian populace from the territory of Croatia during and after World War II"], Radovi Zavoda za povijesne znanosti HAZU u Zadru 55 (2013): 204225; eadem, "Migracije stanovništva na hrvatskom području neposredno prije i nakon završetka Drugoga svjetskog rata" ["Migrations of populace in the territory of Croatia shortly before and after World War II"], Časopis za suvremenu povijest 48 (2016), no. 3: 653-672.

63 Vera Graovac, "Populacijski razvoj Zadra" ["Demographic development of Zadar"], Geoadria 9 (2004), no. 1: 64.

64 Milan Vresk, "Neka obilježja urbanizacije SR Hrvatske 1981. godine" ["Some urbanization features in SR Croatia in 1981"], Acta Geographica Croatica 17-18 (1982-1983), no. 1: 39.

65 Ivo Nejašmić and Aleksandar Toskić, "Razmještaj stanovništva u Republici Hrvatskoj - dio općih demografskih i društveno-gospodarskih procesa" ["Distribution of populace in the Republic of Croatia as part of the general demographic and socioeconomic processes"], Geoadria 5 (2000), no. 1: 97.
} 
ization was massive rural-urban migration. In the first years after World War II, the state focused on industrialization and housing, reconstructing the existing and constructing new housing facilities. The authorities used this creation of living space, as one of the basic human needs, to carry out not only technical, but also cultural and symbolic interventions. Urban areas were especially suitable to show technical progress and the transformation of social and economic relations. Collective housing was promoted as the best model for resolving the housing problem, which resulted in the construction of a number of planned workers' settlements. They were not only a technical solution to the housing problem of an increasing number of residents, but also served to promote the socially organized way of life in a socialist society. This model was supposed to provide a new type of settlement, in which attention would be paid not only to technical equipment, but also to culture and recreation.

Urbanization was paralleled by strong de-agrarization and de-ruralisation, and the depopulation of rural areas deepened the gap between villages and cities. Without technical and communal modernization, rural areas remained without the basic preconditions to keep the young population, and thus without their most important asset. Instead, this development potential was realized in the cities, which were growing both physically and demographically. In the period of socialist modernization, strong institutionalization of urban planning and management was achieved. It was prompted not only by the ideological needs and the paternalistic role of the regime, but also by the actual need to solve economic, social, communal, and environmental problems. There was a discrepancy between the growing number of housing units in the new settlements and the poor communal infrastructure. There were no healthcare facilities, kindergartens, or schools, service providers, cultural centres, or ordered urban environment. An additional difficulty in managing and planning the cities was illegal construction. This phenomenon typically affected the periphery of large cities, where construction of private family houses was common.

Despite these deficiencies, which have been described as "modernization without modernity", socialist modernization also brought positive civilizational and economic shifts, visible in the advance of education, housing, communal and social infrastructure, and the living standard. However, in such technical modernization, which omitted many other elements of development, the urban system evolved unevenly, with the polarization of administrative and economic functions as well as population in the largest cities. Spatially concentrated urbanization in the largest centres resulted in an unevenly developed network of medium-sized and small towns, visible in Croatia to this day. 


\section{Bibliography}

\section{Archival sources}

Archives of Yugoslavia (AJ)-41, Savezna planska komisija [Federal Planning Commission], box 536.

AJ-60, Komitet za lokalnu privredu i komunalne poslove [Committee for Local Economy and Communal Affairs], box 4.

AJ-130, Savezno izvršno veće [Federal Executive Council (SIV)], Savezna skupština. Komisija za urbanizam i uređenje prostora. Osnove politike urbanizacije i prostornog uređenja - teze [Federal Assembly, Commission for Urban Planning and Landscaping, Basics of urban planning and landscaping policy - theses]. January 1969, box 749.

AJ-130, SIV, Stalna konferencija gradova Jugoslavije [Permanent Conference of Yugoslav Cities (SKGJ)], box 749.

AJ-142, Socijalistički savez radnog naroda Jugoslavije [Socialist Union of the Working People of Yugoslavia (SSRNJ)], Stanbena zajednica kao urbanistički element planskog razvoja gradova i drugih naseljenih mesta [Housing community as an element of urban planning in the development of cities and other settlements], box 88 .

Državni arhiv u Rijeci [State Archives in Rijeka, DARI]-78, Narodni odbor kotara Rijeka [National Board of the Rijeka District], Savjet za saobraćaj i pomorsku privredu [Council for Transportation and Maritime Economy], box 9 .

Državni arhiv u Splitu [State Archives in Split, DAST]-119, Urbanistički zavod Dalmacije Split [Dalmatian Institute of Urban Planning Split (UZDS)], Slobodan Bjelajac, Bespravna stambena izgradnja u Splitu [Illegal housing construction in Split], 1970.

DAST-119, UZDS, Program za provedbeni urbanistički plan splitskog poluotoka. Sociološka studija [Programme for the Executive Master Plan of the Split peninsula: A sociological study. Split], 1974.

\section{Published Sources}

Model diferencijacije urbanih, ruralnih i prijelaznih naselja u Republici $\mathrm{Hr}$ vatskoj, Državni zavod za statistiku [State Institute of Statistics], 2011: Metodološke upute, 67. 


\section{Literature}

Alfirević, Đorđe and Sanja Simonović-Alfirević. "Urban Housing Experiments in Yugoslavia 1948-1970,” Spatium 34 (2015): 1-9.

Anić, Tomislav. "Socialist Competition from Soviet Union to Yugoslavia," Review of Croatian history 13 (2017), no. 1: 183-210.

Bežovan, Gojko. "Stanovanje i stambena politika," in: Socijalna politika Hrvatske, ed. Vlado Puljiz. Zagreb: Pravni fakultet Sveučilišta u Zagrebu, 2008.

Dahrendorf, Ralf. "The Strange Death of Socialism," Studies: An Irish Quarterly Review 79/313 (1990): 7-17.

Durkheim, Émile. The Division of Labor in Society. New York: The Free Press, 1947.

Flere, Sergej. "Da li je Titova država bila totalitarna?," Političke perspektive 2 (2012), no. 2: 7-21.

Franić, Tin Sven, Luka Korlaet, and Dubravka Vranić. "Prilog analizi stambenih politika i planske stanogradnje Nizozemske i Hrvatske," Prostor 13 (2005), no. 2: 195-204.

Friedrich, Carl J. and Zbigniew K. Brzezinski. Totalitarian Dictatorship and Autocracy. New York: Praeger, 1956.

Friganović, Mladen. "O demogeografskom procesu u (ne)urbanom prostoru SR Hrvatske,” Dela 6 (1989): 98-106.

Galjer, Jasna and Anđela Galić. "Kultura stanovanja u Zadru 1950-ih u kontekstu afirmacije modernizma," Ars Adriatica 7 (2017): 313-328.

Gelo, Jakov. Demografske promjene u Hrvatskoj od 1780. Do 1981. Zagreb: Globus, 1987.

Graovac, Vera. "Populacijski razvoj Zadra," Geoadria 9 (2004), no. 1: 51-72.

Gulin Zrnić, Valentina. Kvartovska spika. Značenje grada i urbani lokalizmi u Novom Zagrebu. Zagreb: Jesenski i Turk, 2009.

Karakaš Obradov, Marica. "Emigracije talijanskog stanovništva s hrvatskog područja tijekom Drugog svjetskog rata i poraća," Radovi Zavoda za povijesne znanosti HAZU u Zadru 55 (2013): 204-225.

. "Migracije stanovništva na hrvatskom području neposredno prije i nakon završetka Drugoga svjetskog rata," Časopis za suvremenu povijest 48 (2016), no. 3: 653-672. 
Karaman, Igor. "Uloga malog i srednjeg poduzetništva u oblikovanju kapitalističkog privrednog sustava na tlu Hrvatske," Povijesni prilozi 9 (1990), no. 9: 1-36. . Privreda i društvo Hrvatske u 19. stoljeću. Zagreb: Školska knjiga, 1972.

Klempić, Sanja. "Razvoj stambenih naselja Splita nakon Drugog svjetskog rata," Hrvatski geografski glasnik 66 (2004), no. 2: 95-119.

Korov, Goran. "Zajednička ili zasebna? Paradigme u arhitekturi socijalističke Jugoslavije," Kvartal: kronika povijesti umjetnosti u Hrvatskoj 9 (2012), no. 3-4: 48-56.

Križić Roban, Sandra. "Obilježja modernosti na području arhitekture, urbanizma i unutrašnjeg uređenja nakon drugoga svjetskog rata," in: Socijalizam i modernost: umjetnost, kultura, politika: 1950.-1974., ed. Ljiljana Kolešnik. Zagreb: MSU and IPU, 2012. 55-125.

Lipset, Seymour M. Political Man: The Social Bases of Politics. New York: Doubleday, 1960.

Magaš, Damir. "Urbano geografska preobrazba Zadra - Elementi prometnog sustava 1945.-1991.," Geoadria 1 (1996), no. 1: 35-46.

Merkel, Wolfgang. Eine Einführung in die Theorie und Empirie der Transformationsforschung. Opladen: Leske + Budrich bei UTB, 1999.

Nejašmić, Ivo and Aleksandar Toskić. "Razmještaj stanovništva u Republici Hrvatskoj - dio općih demografskih i društveno-gospodarskih procesa," Geoadria 5 (2000), no. 1: 93-104.

Puljiz, Vlado. "Socijalna politika i socijalne djelatnosti u Hrvatskoj u razdoblju 1900.-1960. godine," Ljetopis Studijskog centra socijalnog rada 13 (2006), no. 1: 7-28.

Rogić, Ivan. Tehnika i samostalnost. Okvir za sliku treće hrvatske modernizacije. Zagreb: Hrvatska sveučilišna naklada, 2000.

. "Tri hrvatske modernizacije i uloga elita," in: Upravljačke elite i modernizacija, ed. Drago Čengić and Ivan Rogić. Zagreb: Institut društvenih znanosti Ivo Pilar, 2001. 37-78.

Royce, Edward. Classical Social Theory and Modern Society: Marx, Durkheim, Weber. Lanham, Boulder, New York, and London: Rowman \& Littlefield, 2015.

Rusinow, Dennison. "Understanding the Yugoslav Reforms," The World Today 23 (1967), no. 2: 71-79. 
Seferagić, Dušica. "Stanovanje kao pokazatelj socijalne segregacije u zagrebačkom prostoru," Sociologija sela 47-48 (1975): 73-81.

Kvaliteta života i nova stambena naselja. Zagreb: Hrvatsko sociološko društvo, 1988.

Smith, David M. “The Socialist City," in: Cities After Socialism: Urban and Regional Change and Conflict in Post-Socialist Societies, ed. Gregory Andrusz, Michael Harloe, and Ivan Szelenyi. Oxford and Cambridge: Blackwell, 1996. 70-99.

Štambuk, Maja. "Selo i modernizacija: kratka povijest nesporazuma," in: Prostor iza: kako modernizacija mijenja hrvatsko selo, ed. Maja Štambuk, Ivan Rogić, and Anka Mišetić. Zagreb: Institut društvenih znanosti Ivo Pilar, 2002. 11-26.

Tipps, Dean C. "Modernization Theory and the Comparative Study of Societies: A Critical Perspective," Comparative Studies in Society and History 15 (1973), no. 2: 199-226.

Vresk, Milan. “Neka obilježja urbanizacije SR Hrvatske 1981. godine," Acta Geographica Croatica 17-18 (1982-1983), no. 1: 39-53. . "Urbanizacija Hrvatske 1981-1991.: Osnovni indikatori stupnja, dinamike i karakteristika urbanizacije," Geografski glasnik 54 (1992), no. 1: 99-115.

Wakeman, Rosemary. "Was There an Ideal Socialist City? Socialist New Towns as Modern Dreamscapes," in: Transnationalism and the German City. Studies in European Culture and History, ed. Jeffry Diefendorf and Janet Ward. New York: Palgrave Macmillan, 2014, pp. 105-124. 